\title{
One-Seed Juniper Sapling Use by Goats in Relation to Stocking Density and Mixed Grazing With Sheep
}

\author{
Santiago A. Utsumi, ${ }^{1}$ Andres F. Cibils, ${ }^{2}$ Richard E. Estell, ${ }^{3}$ Terrell T. Baker, ${ }^{4}$ and John W. Walker ${ }^{5}$ \\ Authors are ${ }^{1}$ Assistant Professor, W.K. Kellogg Biological Station and Department of Animal Science, Michigan State University, Hickory Corners, MI 49060, \\ USA; ${ }^{2}$ Associate Professor, Department of Animal and Range Sciences, New Mexico State University, Las Cruces, NM 88003, USA; ${ }^{3}$ Research Scientist, US \\ Department of Agriculture-Agricultural Research Service, Jornada Experimental Range, Las Cruces, NM 88003, USA; ${ }^{4}$ Professor, Extension Animal Science \\ and Natural Resources, New Mexico State University, Las Cruces, NM 88003, USA; and ${ }^{5}$ Professor and Resident Director of Research, Texas AgriLife \\ Research, San Angelo, TX 76901, USA.
}

\begin{abstract}
Suppression of one-seed juniper (Juniper monosperma [Englem.] Sarg.) reinvasion with goats requires achieving levels of defoliation of newly established saplings that eventually kill or suppress plant growth. We tested the effects of stocking density and mixed grazing with sheep on the level of use of one-seed juniper saplings by goats. In summer and spring, groups of 10 does (goats alone, GA) or 5 does and 4 ewes (mixed grazing, MG), grazed $20 \times 30 \mathrm{~m}$ cells infested with saplings $\left(500-533 \cdot \mathrm{ha}^{-1}\right.$; mean: $0.8 \mathrm{~m}$ tall), either continuously for $6 \mathrm{~d}$ (low stocking density, LD) or with daily rotation through $10 \times 10 \mathrm{~m}$ cells during the 6-d period (high stocking density, HD) in a block design. Feeding activity; juniper in feces; utilization of herbaceous vegetation; frequency of saplings with light, moderate, and heavy foliage and bark use; and branch utilization were determined. Goats in HD spent more time feeding on saplings, less time feeding on herbaceous forages, and tended to consume more juniper than goats in LD. Utilization of herbaceous vegetation ranged from $52 \%$ to $73 \%$ and was higher for MG than GA and for LD than HD. The MG-HD treatment resulted in the highest frequency of short saplings $(<0.5 \mathrm{~m})$ with heavy defoliation in summer and spring, and lowest frequency of saplings with light debarking in spring. Heavy defoliation was more frequent in short saplings, whereas heavy debarking was more frequent in tall $(>1 \mathrm{~m})$ saplings. Sapling mortality was not affected by treatments $(P>0.05)$ and averaged $5 \%$ across treatments. Branch debarking was greater in spring $(P=0.02)$ and explained approximately $80 \%$ of branch mortality and $62 \%$ and $52 \%$ of the reduction in sapling live crown height and volume. Branch utilization (percent length) was not affected by grazing treatments (range: $45-48 \%$ ), but was influenced by the length and diameter of branches. This study suggests that high stocking density and mixed grazing stimulate feeding behaviors that increase utilization of juniper saplings by goats. Susceptibility of saplings to defoliation and debarking varies with sapling size, branch structure, and season. Targeted grazing in spring appears to have a greater impact on sapling suppression and branch mortality due to higher debarking frequency.
\end{abstract}

\section{Resumen}

El control de la reinvasión de Juniperus monosperma mediante el uso de cabras require alcanzar niveles de defoliación que aumenten la mortalidad o supriman el crecimiento de renovales. Se determinaron los efectos de densidad animal y pastoreo mixto con ovejas sobre los niveles de uso de J. monosperma por cabras. En verano y primavera, grupos de 10 cabras (cabras solas, CS) o de 5 cabras con 4 ovejas (pastoreo mixto, PM), pastorearon parcelas de $20 \times 30$ m invadidas con renovales de J. monosperma $(500-533$ individuos/ha, altura media: $0.8 \mathrm{~m}$ ), bajo pastoreo continuo por 6 días (Baja densidad, BD) o con rotación diaria en parcelas de $10 \times 10 \mathrm{~m}$ durante 6 días (Alta densidad, AD), siguiendo un diseño en bloques. Se determinó la actividad durante el pastoreo, J. monosperma en fecas, utilización de la vegetación herbácea, frequencia de renovales con defoliación, leve, moderada, o alta, y utilización de corteza y ramas. Las cabras en el tratamiento de $\mathrm{AD}$ pasaron mas tiempo ramoneando renovales, menos tiempo pastoreando vegetación herbácea y tendieron a consumir mas J. monosperma que las cabras en el tratamiento de $\mathrm{BD}$. El rango de utilización de vegetación herbácea fue entre $52 \%$ y $73 \%$ y fue mayor para PM que para CS y para $\mathrm{BD}$ que $\mathrm{AD}$. El tratamiento PM-AD resultó en mayor frecuencia de renovales bajos $(<0.5 \mathrm{~m})$ con alta defoliacion en verano y primavera, y menor frecuencia de renovales con baja utilizacion de corteza. Niveles altos de defoliación fueron más frecuentes en renovales bajos, mientras que altos niveles de descortezado fueron mas frecuentes en renovales altos $(>1 \mathrm{~m})$. La mortalidad de renovales no fue afectada por los tratamientos $(P>0.05)$ y fue en promedio del $5 \%$. El descortezado de ramas fue mayor en primavera $(P=0.02)$ y explicó aproximadamente el $80 \%$ de la mortalidad de ramas, y el $62 \%$ y $52 \%$ de la reducción en altura y volumen de copa. La utilización de ramas (\% del largo) no fue afectada por los tratamientos (rango 45-48\%), pero fue influenciada por el largo y diámetro de los tallos. Este estudio sugiere que alta densidad animal y pastoreo mixto estimulan comportamientos de forrajeo que aumentan la utilización de renovales de $J$. monosperma por cabras. La susceptibilidad de defoliación y descortezado de renovales varía con el tamaño, estructura de ramas y estación. El pastoreo prescipto de primavera aparenta tener mayor impacto sobre la supresión y mortalidad de ramas debido a la mayor frecuencia de descortezado.

Key Words: diet mixing, grazing systems, juniper control, targeted grazing

This study was funded with a grant from the US Department of Agriculture, Cooperative State Research, Education, and Extension Service, Joe Skeen Institute for Rangeland Restoration, and contributions from the Corona Range and Livestock Research Center (CRLRC) and Texas AgriLife Research, San Angelo, TX, USA.

At the time of the research, Utsumi was a PhD candidate, Dept of Animal and Range Sciences, New Mexico State University, Las Cruces, NM 88003, USA.

Correspondence: Andres F. Cibils, Dept of Animal and Range Sciences, New Mexico State University, Las Cruces, NM 88003, USA. Email: acibil@@nmsu.edu

Manuscript received 20 October 2008; manuscript accepted 4 January 2010. 


\section{INTRODUCTION}

One-seed juniper (Juniperus monosperma [Engelm. Sarg.]) is a widespread native evergreen woody species that currently dominates several million hectares of midelevation (ca. 2000 $3000 \mathrm{~m}$ ) rangelands in south-central New Mexico and eastcentral Arizona, which typically receive $25-40 \mathrm{~cm}$ precipitation as late summer monsoons (Romme et al. 2008). Although oneseed juniper-dominated rangelands provide important ecosystem services and aesthetic values, they are primarily used for livestock grazing (Pieper 1990).

The ecological dynamics of juniper stands are thought to have changed since Euro-American settlement as a result of overgrazing and associated changes in fire regimes (Romme et al. 2008). Juniper woodlands are thought to have expanded in range and density, causing a decrease in diversity and productivity of understory vegetation (Schott and Pieper 1985; Armentrout and Pieper 1988; Pieper 1990) and an increase in shading, litter accumulation, root competition, water consumption, and allelopathic interference (Arnold 1964; Jameson 1966, 1967, 1970). Because of this phenomenon, tree clearing has been practiced extensively in an attempt to promote transitions from degraded woodlands to savanna grassland states. Nevertheless, high sapling reinvasion rates following tree-clearing continue to pose a major challenge for land managers seeking to maintain open juniper savanna landscapes.

Suppression of one-seed juniper saplings at early stages of development should minimize the probability of juniper woodland reestablishment. Targeted grazing with goats has been proposed as a means of suppressing seedling recruitment of various undesirable woody species (Launchbaugh and Walker 2006), and could be used to extend the life span of other more traditional juniper control methods such as fire. Targeted grazing with goats may reduce the density of one-seed juniper saplings or suppress sapling growth and maintain rangelands beneath thresholds of woody plant dominance (Archer 1995).

Successful targeted grazing programs require strategies that boost voluntary intake of target woody plants while minimizing understory vegetation damage. One-seed juniper contains phenolics (Nunez-Hernandez et al. 1989) and terpenes (Utsumi et al. 2006, 2009) that deter ruminant herbivory (Schwartz et al. 1980a; Riddle et al. 1996) because of bactericidal and toxic effects on rumen microorganisms and animal hosts (Schwartz et al. 1980b; Nunez-Hernandez et al. 1989; Pritz et al. 1997; Riddle et al. 1999). Breed and individual animal selection, manipulation of season of grazing, and use of protein supplements have all been suggested as strategies to improve juniper utilization by goats (Riddle et al. 1996; Campbell et al. 2007; Walker et al. 2007). Implementation of specialized grazing systems has been proposed as another option. Heavy stocking rates with tight control of temporal allocation of forages apparently forces herbivores to increase diet mixing and to switch among preferred forages and chemically defended plants more frequently (Shaw et al. 2006; Provenza et al. 2007). Short and frequent feeding bouts on chemically defended plants and complementary forages are thought to favor intake of chemically defended plants because herbivores 1 ) are able to dilute toxins better (Freeland and Jansen 1974), 2) are allowed sufficient time to detoxify plant secondary metabolites (Foley et al. 1999; Wiggins et al. 2006), and 3) achieve temporal synchrony of dietary nutrients and toxins, which allows them to mitigate the detrimental effects of toxins (Villalba et al. 2006).

Mixed-species grazing with goats and sheep could also induce an increase in diet breadth of goats through competition for preferred resources shared by both herbivores (Walker 1994; Animut and Goestch 2008). Stocking density and mixed grazing with sheep and goats have been successfully used (either alone or combined) to improve utilization of a number of chemically defended plants, such as big sagebrush (Artemisia tridentata; Shaw et al. 2006), redberry juniper (Juniperus pinchotti Sudw.; Ueckert 1997), and leafy spurge (Euphorbia esula L.; Schauer et al. 2004). However, there is no research evaluating the combined impact of these techniques on use of one-seed juniper saplings by goats.

The objectives of this study were to determine 1) the effects of grazing management strategies on the feeding behavior of goats and sheep, 2) the amount of one-seed juniper in the diets of goats grazing alone or in combination with sheep at two contrasting stocking densities, 3) the frequency of sapling use and herbaceous understory utilization associated with the grazing strategies applied, 4) the influence of grazing management strategies on sapling growth and survival rates, and 5) the effects of sapling branch structural attributes (i.e., length and stem diameter) on the extent of utilization. The hypotheses tested were that 1) mixed grazing with sheep and high stocking density would stimulate feeding behaviors associated with diet mixing that would lead to greater intake and use of one-seed juniper saplings by goats, 2) mixed grazing and low stocking density would lead to greater utilization of understory vegetation, 3) grazing strategies that promote higher sapling use would also induce higher sapling mortality rates, and 4) the length and diameter of one-seed juniper branches would restrict utilization by small ruminants.

\section{MATERIALS AND METHODS}

\section{Study Site}

The study was conducted at New Mexico State University's Corona Range and Livestock Research Center (CRLRC) during July and August 2006 (summer) and May and June 2007 (spring). The CRLRC straddles the border between Torrance and Lincoln counties in central New Mexico (lat $34^{\circ} 15^{\prime} 36^{\prime \prime} \mathrm{N}$, long $105^{\circ} 24^{\prime} 36^{\prime \prime} \mathrm{W}$; elevation $\left.=1900 \mathrm{~m}\right)$. Average annual rainfall is $327 \pm 96 \mathrm{~mm}$ ( $15-\mathrm{yr}$ mean \pm range), with $65 \%$ occurring from May to September (Majumdar 2006). The study was set up on a loamy ecological site dominated by the Tapia-Dean soil association, with gentle to moderate topography, and soils with good moisture-storage capacity (US Department of Agriculture Soil Conservation Service 1970). Above-average precipitation in July and August of 2006 $(224 \mathrm{~mm})$ and again in May and June of 2007 (106 mm) promoted high-standing biomass of perennial grasses and forbs at the site prior to beginning the grazing trials (Table 1). Dominant grasses were Bouteloua gracilis (blue grama), Bouteloua curtipendula (sideoats grama), Lycurus setosus (wolftail), Sporobolus airoides and Sporobolus cryptandrus 
Table 1. Herbaceous standing biomass and juniper sapling density and crown characteristics in spring 2007 and summer 2006. Values are means $( \pm$ SE) of all grazing cells $(n=16)$.

\begin{tabular}{lcc}
\hline \multicolumn{1}{c}{ Vegetation attribute } & Spring & Summer \\
\hline Herbaceous biomass $\left(\mathrm{kg} \cdot \mathrm{ha}^{-1}\right)$ & $962.30 \pm 98.99$ & $1462.91 \pm 75.36$ \\
Juniper sapling density & & \\
$\quad\left(\right.$ saplings $\left.\cdot \mathrm{ha}^{-1}\right)$ & $500.04 \pm 55.63$ & $533.33 \pm 49.40$ \\
Average sapling height $(\mathrm{m})$ & $0.89 \pm 0.03$ & $0.79 \pm 0.03$ \\
Average sapling crown diameter $(\mathrm{m})$ & $0.86 \pm 0.03$ & $0.71 \pm 0.03$ \\
Average sapling canopy volume $\left(\mathrm{m}^{3}\right)$ & $1.12 \pm 0.10$ & $0.76 \pm 0.12$ \\
\hline
\end{tabular}

(dropseeds), and Aristida purpurea (threeawn). Dominant forbs included Descurainia obtusa and Descurainia pinnata (tansy mustards), Glandularia bipinatifida (pink vervain), Ipomoea costellata (morning glory), Draba cuneifolia (white draba), Physeria spp. (bladderpods), Evolvulus nuttallianus (wooly evolvulus), Linium lewisii (western blue flax), Linium puberulum (orange flax), Asclepias spp. (milkweeds), Penstemon spp. (penstemons), Helianthus petiolaris (prairie sunflower), Solanum elaeagnifolium (silverleaf), Pomaria jamesii (caesalpinia), Tragia ramosa (noseburn), Chameasyce spp. (spurge), Tradescantia occidentalis (spiderwort), Astragalus mollissimus (wooly locoweed), and Astragalus missouriensis (Missouri milkvetch). Lycium pallidum (wolfberry), an understory shrub, was also present in sporadic patches. One-seed juniper was the dominant woody species along with scattered pinyon pine (Pinus edulis) saplings. The desired potential plant community on this ecological site is characterized by a mixture of mid- and short grasses, scattered shrubs and half-shrubs, and one-seed juniper and pinyon trees increasing in density as elevation increases (US Department of Agriculture Natural Resources Conservation Service 2009). The area of the pasture containing our experimental site had been mechanically cleared in the late 1980s, and is currently heavily reinfested with juniper saplings (Table 1 ). This pasture is grazed lightly by $2-3$-yr-old cows every winter, and no record of prior grazing by goats exists.

\section{Experiment Protocol}

Fifteen mature open Boer $\times$ Spanish does $(47.9 \pm 1.1 \mathrm{~kg}$; mean \pm SE) and four mature open Western White Face ewes $(69.2 \pm 0.9 \mathrm{~kg})$ raised on New Mexico rangelands and not naive to juniper were used in the summer and spring grazing trials. Experiment protocols were approved by the New Mexico State University Institutional Animal Care and Use Committee. Prior to grazing trials in each season, a 7-d preexperimental grazing phase was used to adapt animals to weather conditions, vegetation, daily grazing management, and supplementation.

Treatments were a combination of two animal groups (1.1 animal units per group) composed of either 10 does (goats alone [GA]) or 5 does and 4 ewes (mixed grazing [MG]), and two stocking densities, either high (HD) or low (LD). The GA and MG groups grazed in $20 \times 30 \mathrm{~m}$ experimental cells $11 \mathrm{~h}$ per day (0700 to 1800 hours) for 6-d periods, either continuously (LD treatment) or with daily rotation through $10 \times 10 \mathrm{~m}$ subcells (HD treatment). In this way, stocking density treatments (number of animals per grazeable area at a given time) were achieved by modifying the daily space
Table 2. Composition of protein supplement fed to goats and sheep in all treatments.

\begin{tabular}{|c|c|}
\hline Ingredient & Amount $\left(\mathrm{g} \cdot \mathrm{kg}^{-1}\right)$ \\
\hline Soybean meal $45 \%$ & 480.0 \\
\hline Fish meal $60 \%$ & 412.8 \\
\hline Ground corn & 67.2 \\
\hline Mineral-vitamin premix ${ }^{1}$ & 40.0 \\
\hline Metabolizable energy $\left(\mathrm{Mcal} \cdot \mathrm{kg}^{-1}\right.$ ) & 2.50 \\
\hline Crude protein (\%) & 46.90 \\
\hline
\end{tabular}

allowance while maintaining a constant stocking rate (i.e., total area allocated per animal over $6 \mathrm{~d}$ ) of $3.3 \mathrm{ha} \cdot \mathrm{AUY}^{-1}$ across treatments (AUY $=$ animal unit year). This stocking rate provided an average daily herbage allowance of $70 \mathrm{~g} \cdot \mathrm{kg}^{-0.75}$ for goats and $53 \mathrm{~g} \cdot \mathrm{kg}^{-0.75}$ for sheep, which met maintenance intake requirements of does and ewes (National Research Council 1981, 1985). Thus, the HD and LD treatments offered different temporal allocation of the same amount of herbaceous forage, whereas the GA and MG differed in livestock species. Prior data on juniper intake of individual animals were used to stratify does into high or low juniper eaters and to assign them in equal proportions to GA or MG treatments. Does remained in GA or MG throughout the study.

In each season, GA and MG groups grazed at $\mathrm{LD}$ and $\mathrm{HD}$ in two consecutive 6-d periods in two contiguous groups of grazing cells to achieve two complete blocks per season. In each block, one additional neighboring cell $(20 \times 30 \mathrm{~m})$ was excluded from grazing and kept as a control. With this arrangement, GA and MG grazed blocks switched from HD to LD or vice versa. This sequence order was randomly determined in each season. Every day at sunset, animals were moved to a corral and individually fed a high-protein supplement at $0.45 \%$ body weight (Table 2 ). This supplementation regime was expected to sustain stocking rates and improve one-seed juniper intake of goats (Utsumi et al. 2009). Electric fence nets (Kencove Supplies, Blairsville, PA) were used to contain animals within grazing cells. The body weight of each animal was recorded $( \pm 0.1 \mathrm{~kg})$ prior to beginning and at the end of grazing trials in each season.

Daily activity scans were conducted to estimate the time goats and sheep spent feeding on herbaceous vegetation and juniper, time spent resting or ruminating (either standing or laying), and number and length of herbaceous vegetation and juniper feeding bouts. Each animal's activity was recorded at 2min intervals for 3 consecutive hours in the morning (07001000 hours) and afternoon (1500-1800 hours). A juniper feeding bout was defined as a series of consecutive scans in which animals were observed browsing juniper saplings followed either by a single scan or a series of scans feeding on herbaceous vegetation, resting, ruminating, or watering. The same criterion was used to define an understory feeding bout. The length of a feeding bout ( $\mathrm{min}$ ) was calculated by multiplying the number of consecutive scans by the interval time between scans (2 min). Activity scans on GA or MG treatment animals were made on alternate days for each 6-d grazing period. The day in which GA or MG was observed (1, 
3 , and 5, or 2, 4, and 6) was reversed between periods and pooled into beginning (days 1-2), middle (days 3-4), and end (days 5-6) of a grazing trial to provide comparative trends of feeding behavior among treatments.

Fecal samples $(20 \mathrm{~g})$ were collected by rectal palpation from each animal on day 6 of each period and analyzed to determine the percentage of one-seed juniper in diets with the use of the near-infrared reflectance spectroscopy (NIRS) method. Calibration equations were based on equations developed for Ashe (Juniperus ashei) and redberry (J. pinchotii) juniper as described by Walker et al. (2007). A preliminary test in which four sheep and four goats were individually fed known amounts of sudangrass and alfalfa with $0 \%, 10 \%$, and $30 \%$ one-seed juniper revealed these equations accurately predicted one-seed juniper in small ruminant diets $\left(R^{2}=0.89, n=24\right)$. To improve predictions further, fecal samples from two ewes and two does grazing neighboring grazing cells devoid of juniper were collected and used as a control (zero juniper). Control animals were subjected to the same fecal sampling schedule and daily management as experimental animals.

Data collected for juniper saplings included density, height, crown diameter, and canopy volume prior to grazing. Frequency of defoliation and debarking of saplings and branch utilization were measured immediately after grazing treatments. Sapling height $( \pm 0.1 \mathrm{~m})$ was measured from the ground to the tip of the tallest branch. Crown diameter $( \pm 0.1 \mathrm{~m})$ was calculated as the average between the longest horizontal axis and its perpendicular diameter. Height and crown-diameter data were used to calculate canopy volume of saplings assuming a half-spheroid shape (Bonham 1989). Height measurements were used to classify individual saplings into tall $(>1 \mathrm{~m})$, medium $(1-0.5 \mathrm{~m})$, and short $(<0.5 \mathrm{~m})$ size categories; estimates of defoliation and debarking frequency and branch utilization were calculated for each sapling size class.

Defoliation and debarking of saplings were estimated in both seasons following Bonham (1989). Percent browsed branches ([browsed branches/total branches] $\times 100$ ) was used to classify saplings into defoliation categories $(0-33 \%, 34-66 \%$, and $67-$ $100 \%)$. Frequency of saplings in each defoliation category was then calculated for tall, medium, and short saplings in each grazing cell. Percent debarked branches ([debarked branches/ total branches] $\times 100)$ was used to classify saplings into debarking categories $(0-33 \%, 34-66 \%$, and $67-100 \%)$, and frequency of saplings in each debarking category was then calculated for tall, medium, and short saplings in each grazing cell. Branch utilization was determined on 10 marked branches of three saplings in each size category in every grazing cell. Branches were marked at the base with thin, colored electrical tape and initial (before grazing) and final (after grazing) length $( \pm 0.1 \mathrm{~cm})$ of branches was recorded. Basal and cutoff (i.e., point at which branches were clipped by browsing) diameter $( \pm 0.5 \mathrm{~mm})$ of branches were also measured in spring. Utilization of marked branches was estimated as the percent length removed by browsing $\left(\left[\right.\right.$ length ${ }_{i}-$ length $\left._{f}\right] /$ length $\left._{i} \times 100\right)$.

In January 2009, two complete growing seasons following the summer and spring grazing treatments, we measured live canopy height, diameter, and volume of saplings using the crown measurement protocol described above. In addition, we recorded mortality rates of saplings and individual branches.
Sapling mortality ([dead saplings/total saplings] 100) was determined for each grazing cell. Branch mortality ([dead branches/total branches] · 100) was determined for each sapling and averaged across saplings occurring in each grazing cell.

Understory vegetation biomass was measured before and after grazing by clipping $240.2-\mathrm{m}^{2}$ rectangular frames placed $5 \mathrm{~m}$ apart along four $\mathrm{N}-\mathrm{S}$ transects in each cell. Biomass samples were placed in paper bags, dried in an oven at $60^{\circ} \mathrm{C}$ for $72 \mathrm{~h}$, and weighed $( \pm 1 \mathrm{~g})$ and were used to estimate percent utilization of herbaceous understory vegetation for each grazing cell ([biomass before grazing - biomass after grazing/ biomass before grazing] 100 ).

\section{Statistical Analysis}

Analysis of variance (ANOVA) was conducted with grazing cells used as experimental units. The mixed model used to analyze the time goats spent resting, ruminating, or feeding on juniper or herbaceous vegetation, and the number and length of juniper or herbaceous vegetation feeding bouts contained season of grazing (summer and spring), block nested within season ( $\mathrm{A}$ and $\mathrm{B}$ ), herbivore species (GA and $M G)$, stocking density (HD and LD), trial stage (day 1-2: beginning, day 3-4: middle, and day 5-6: end), and all two-way interactions between herbivore species, stocking density, and trial stage as independent variables. In this model, trial stage was treated as a repeated measure with the use of a first-order autoregressive (AR[1]) covariance structure previously tested with the Bayesian information criterion (Littell et al. 1998). Grazing cell nested within season $\times$ herbivore species $\times$ stocking density was the error term used to test season, herbivore species, stocking density, and the interaction between herbivore species and stocking density. Trial stage and its interactions were tested with the use of the residual as the error term.

The effect of stocking density (HD or LD) on the feeding behavior of sheep in the mixed grazing treatment was analyzed with a mixed model containing season, block nested within season, stocking density, trial stage, and the interaction between stocking density and trial stage as independent variables. In this model, trial stage was the repeated measure that was modeled with the use of a first-order autoregressive (AR[1]) covariance structure. Grazing cell nested within season by stocking density interaction was the error term used for testing season and stocking density. Fecal juniper content (\%, NIRS determination) of sheep was analyzed in a separate model that included season, block nested within season, and stocking density as independent variables, all of which were tested with the residual as the error term.

Fecal juniper content ( $\%$; NIRS determination) of goats, utilization of herbaceous vegetation (\%), frequency of saplings in each defoliation and debarking category and sapling size category (tall, medium, and short), and utilization of individual branches ( $\%$ branch length removed) were analyzed with a model that included season, block nested within season, herbivore species, stocking density, and the interaction between herbivore species and stocking density as independent terms, all of which were tested with the use of the residual as the error term. Differences between short, medium, and tall saplings in frequency of defoliation and frequency of debarking in each defoliation and debarking category, structural branch attri- 
Table 3. Feeding behavior of goats grazing as a single species or mixed with sheep at either high or low stocking density in grazing cells heavily infested with one-seed juniper saplings during the entire study (summer + spring, $n=16$ ). The $P$ values are from the mixed-model analysis of variance testing the effect of herbivore species (Herb), stocking density (Dens), and their interaction. Values are means \pm standard error.

\begin{tabular}{|c|c|c|c|c|c|c|c|}
\hline \multirow[b]{2}{*}{ Variable } & \multicolumn{2}{|c|}{ Goats alone } & \multicolumn{2}{|c|}{ Goats mixed } & \multicolumn{3}{|c|}{$P$ value } \\
\hline & High & Low & High & Low & Herb & Dens & Herb $\times$ Dens \\
\hline Time feeding (\% scans) & $45.2 \pm 5.6$ & $43.7 \pm 3.6$ & $47.0 \pm 6.1$ & $52.2 \pm 6.6$ & 0.146 & 0.355 & 0.354 \\
\hline Time ruminating (\% scans) & $13.4 \pm 1.7$ & $14.0 \pm 0.2$ & $14.5 \pm 2.0$ & $12.2 \pm 1.8$ & 0.681 & 0.425 & 0.274 \\
\hline Time resting (\% scans) & $38.7 \pm 3.9$ & $39.4 \pm 2.8$ & $35.2 \pm 4.1$ & $32.5 \pm 5.5$ & 0.064 & 0.396 & 0.549 \\
\hline Time feeding herbaceous vegetation (\% scans) & $71.2 \pm 3.7$ & $77.4 \pm 0.6$ & $66.7 \pm 6.8$ & $82.2 \pm 2.1$ & 0.783 & 0.006 & 0.116 \\
\hline Time feeding juniper (\% scans) & $28.8 \pm 3.7$ & $22.6 \pm 0.6$ & $33.3 \pm 6.8$ & $17.8 \pm 2.1$ & 0.783 & 0.006 & 0.116 \\
\hline \multicolumn{8}{|l|}{ Fecal juniper (\% near-infrared reflectance } \\
\hline spectroscopy) & $26.8 \pm 2.7$ & $21.7 \pm 3.0$ & $29.5 \pm 2.5$ & $22.8 \pm 3.8$ & 0.639 & 0.067 & 0.706 \\
\hline Total feeding bouts & $19.9 \pm 2.4$ & $19.8 \pm 3.2$ & $21.8 \pm 2.8$ & $20.2 \pm 1.8$ & 0.354 & 0.488 & 0.533 \\
\hline Feeding bouts juniper & $8.6 \pm 1.1$ & $6.8 \pm 1.1$ & $9.1 \pm 1.2$ & $7.5 \pm 0.6$ & 0.361 & 0.030 & 0.955 \\
\hline Feeding bouts herbaceous vegetation & $11.3 \pm 1.3$ & $13.0 \pm 2.3$ & $12.7 \pm 1.8$ & $12.7 \pm 1.4$ & 0.551 & 0.235 & 0.325 \\
\hline Length juniper bouts (min) & $3.6 \pm 0.2$ & $3.3 \pm 0.2$ & $4.2 \pm 0.6$ & $3.4 \pm 0.4$ & 0.157 & 0.063 & 0.250 \\
\hline Length herbaceous vegetation bouts (min) & $8.3 \pm 1.1$ & $7.7 \pm 0.7$ & $7.9 \pm 1.6$ & $10.9 \pm 1.8$ & 0.314 & 0.259 & 0.098 \\
\hline
\end{tabular}

butes (length and diameter) and utilization of branches were tested with a model that included sapling size category as the independent variable. Nonlinear regression analysis was used to model the relationships between branch structural attributes and utilization levels.

Change in sapling live canopy height, diameter, and volume, frequency of sapling mortality, and frequency of branch debarking and mortality 2 years after grazing treatments were analyzed with a model that included season, block nested within season, and treatments (Control, GA-HD, GA-LD, GMHD, GM-LD) as independent terms, all of which were tested with the residual used as the error term. Linear regression was used to model the relationship between frequency of branch debarking $(\mathrm{x})$ and branch mortality, and change in sapling live crown height and volume.

Pearson correlation analysis between the time goats spent feeding on juniper ( $\%$ scans) and percent juniper in the diet (based on fecal NIRS determination) was used to provide a conservative validation of the accuracy of NIRS fecal spectra for predicting one-seed juniper utilization. A pairwise $t$ test was conducted to compare the body weight of animals (goats alone $[n=10]$ and goats $[n=5]$ and sheep $[n=4]$ in the mixed grazing treatment) before and after grazing trials in each of the seasons. All ANOVA, correlation, and linear and nonlinear regression analyses were conducted with the SAS statistical package v 9.1.3 (SAS 2004). When significant effects for ANOVA analyses were detected (alpha value $=5 \%$ ), mean separation analysis was conducted by Fisher's Protected LSD test with significance declared at $5 \%$ alpha value $\left(\mathrm{LSD}_{0.05}\right)$.

\section{RESULTS}

\section{Feeding Behavior}

No block $(P>0.26)$ or season $(P>0.14)$ effect was detected on time spent ( $\%$ scans) feeding, resting, and ruminating, time feeding on herbaceous vegetation and juniper, and number and length of juniper and herbaceous vegetation feeding bouts by goats. Goats in GA or MG treatments spent the same total proportion of time feeding, resting, and ruminating (\% scans) at high or low stocking density (Table 3). Nonetheless, grazing treatments affected how goats partitioned their feeding time between juniper and herbaceous vegetation. The proportion of time spent browsing juniper ( $\%$ feeding scans) was higher at high stocking density, whereas time spent grazing herbaceous vegetation was lower at high stocking density (Table 3 ). This vegetation-use pattern tended to be more pronounced for goats in the MG vs. the GA treatment (Table 3). Goats in GA and MG treatments had greater number and length of juniper feeding bouts in the high stocking density treatment (Table 3).

Feeding activity of goats varied with days. As days progressed, goats spent less time grazing herbaceous vegetation $(P<0.01)$ and more time browsing juniper $(P<0.01)$. Number $(P<0.01)$ and length of juniper feeding bouts $(P<0.01)$ also increased with days. These trends in feeding behavior of goats differed between treatments and were most evident in the MG and high stocking density treatments (Fig. 1). By the final stage (days 5-6) of the 6-d grazing periods, goats in GA exhibited fewer feeding bouts $(P<0.05)$ on herbaceous vegetation, whereas goats in MG exhibited a higher number of longer feeding bouts on juniper $(P<0.05$; Fig. 1$)$. Similarly, goats in high stocking density treatments had fewer and shorter feeding bouts on herbaceous vegetation and longer feeding bouts on juniper than goats in low stocking density treatments during the final stage (days 5-6) of grazing periods (Fig. 1).

No block $(P>0.19)$ or season $(P>0.15)$ effects were detected for variables describing the feeding behavior of sheep. Sheep in the MG treatments spent a similar proportion of time (\% scans) feeding, resting, and ruminating, and did not change the proportion of time devoted to eating juniper or herbaceous vegetation ( $\%$ feeding scans), or number and length of feeding bouts as a consequence of stocking density (Table 4). However, as the 6-d grazing periods progressed, ewes spent increasingly more time feeding on juniper and progressively less time feeding on herbaceous vegetation $(P<0.01)$, particularly when stocking density was high $(P<0.05$; Fig. 2$)$. Ewes in this treatment exhibited an increasing number of juniper feeding bouts and progressively shorter herbaceous vegetation feeding 
HERBIVORE SPECIES
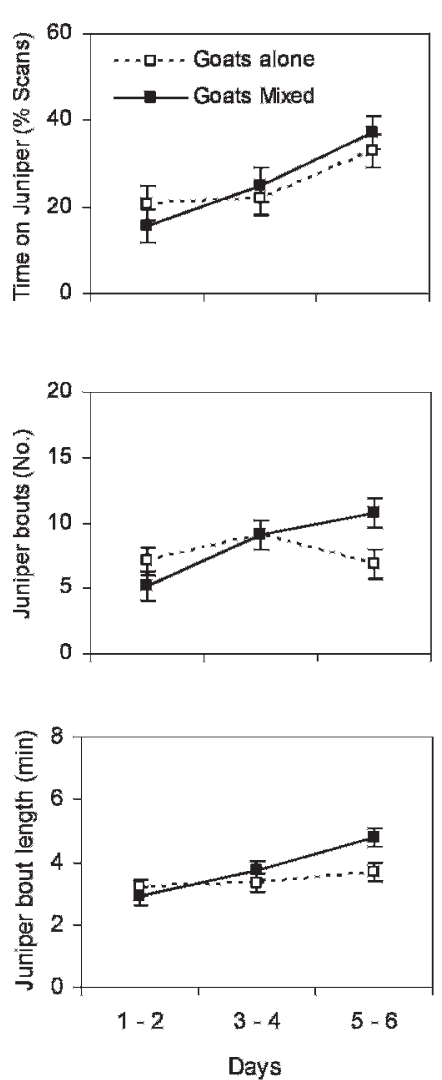
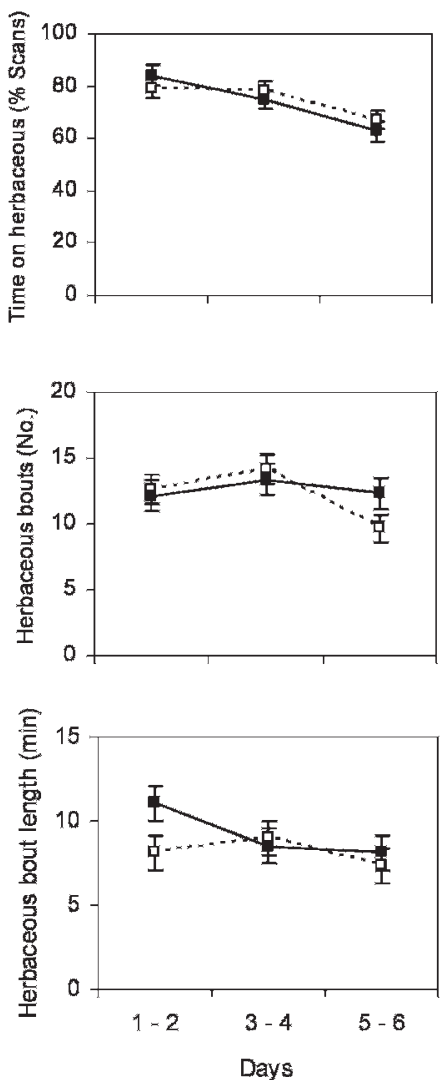

STOCKING DENSITY
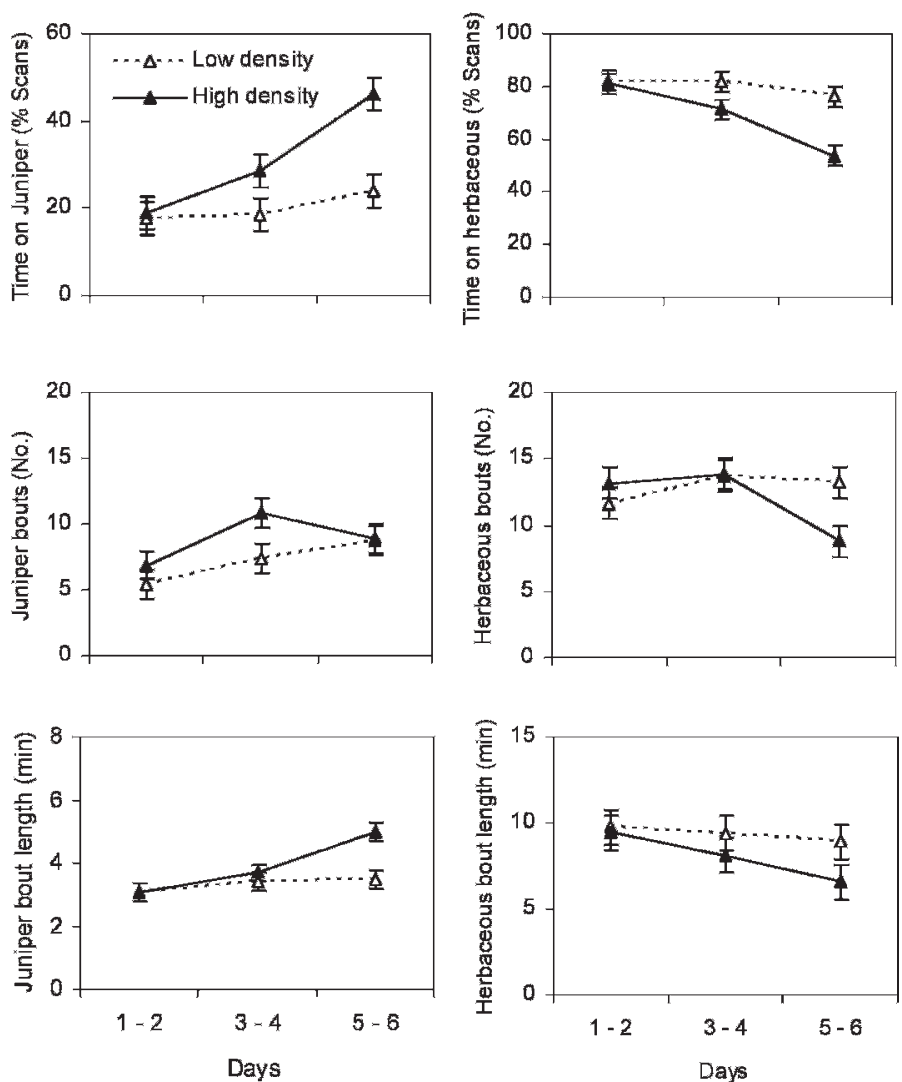

Figure 1. Feeding behavior of goats in single or mixed-species (goats + sheep) grazing (average of low and high stocking densities shown) and at high or low stocking density (average of goats grazing alone and cograzing with sheep are shown) during $6 \mathrm{~d}$ in cells heavily infested with one-seed juniper saplings. Bars denote standard error of means.

Table 4. Feeding behavior of sheep cograzing with goats at either high or low stocking density in grazing cells heavily infested with one-seed juniper saplings $(n=8)$. The $P$ values are from the mixed model analysis of variance testing the effect of stocking density. Values are means \pm standard error.

\begin{tabular}{lrrr}
\hline & \multicolumn{2}{c}{ Stocking density } & \\
\cline { 2 - 3 } \multicolumn{1}{c}{ Variable } & \multicolumn{1}{c}{ High } & \multicolumn{1}{c}{ Low } & P value \\
\hline Time feeding (\% scans) & $68.3 \pm 8.5$ & $66.7 \pm 5.6$ & 0.253 \\
Time ruminating (\% scans) & $12.2 \pm 2.6$ & $14.4 \pm 3.3$ & 0.484 \\
Time resting (\% scans) & $16.1 \pm 5.6$ & $16.2 \pm 3.2$ & 0.711 \\
Time feeding herbaceous & & & \\
$\quad$ vegetation (\% scans) & $91.0 \pm 2.6$ & $92.9 \pm 0.7$ & 0.468 \\
Time feeding juniper (\% scans) & $9.0 \pm 2.6$ & $7.1 \pm 0.7$ & 0.468 \\
Fecal juniper (\% NIRS ${ }^{1}$ ) & $15.1 \pm 1.7$ & $13.6 \pm 2.9$ & 0.350 \\
Total feeding bouts & $18.9 \pm 2.9$ & $16.3 \pm 2.0$ & 0.388 \\
Feeding bouts juniper & $5.7 \pm 1.5$ & $4.5 \pm 0.5$ & 0.576 \\
Feeding bouts herbaceous & & & \\
$\quad$ vegetation & $13.1 \pm 1.7$ & $11.8 \pm 1.5$ & 0.380 \\
Length juniper bouts (min) & $2.5 \pm 0.3$ & $3.1 \pm 0.2$ & 0.317 \\
Length herbaceous vegetation & & & \\
$\quad$ bouts (min) & $16.8 \pm 2.8$ & $17.8 \pm 3.0$ & 0.889 \\
\hline 1№s indigates near-infrared reflectance & & & \\
\hline
\end{tabular}

${ }^{1} \mathrm{NIRS}$ indicates near-infrared reflectance spectroscopy. bouts as trials progressed $(P<0.05$; Fig. 2$)$. Overall, the proportion of time sheep spent feeding on juniper (mean \pm SE, $8.0 \pm 1.1 \%$ scans) was about threefold lower than that of companion goats in the MG treatment $(25.2 \pm 0.9 \%)$. Conversely, sheep spent more time grazing herbaceous forage $(92.0 \pm 1.1 \%)$ than companion goats $(74.8 \pm 0.9 \%)$ in the $\mathrm{MG}$ treatment.

\section{Fecal Juniper}

No block effect was detected in fecal juniper concentration of goats $(P=0.58)$ or sheep $(P=0.19)$. Fecal juniper concentration tended to be higher for goats in the high vs. the low stocking density treatment (Table 3), supporting behavioral observations for time goats spent feeding on juniper. Goats in the MG and GA treatments had similar amounts of juniper in feces (Table 3). Amount of juniper in goat feces tended to vary with season $(P=0.10)$, and was (means $\pm \mathrm{SE}$ ) $28.0 \pm 2.4 \%$ and $22.4 \pm 1.5 \%$ for summer and spring, respectively. Sheep in the high and low stocking density treatments exhibited similar amounts of fecal juniper ( $\mathrm{Ta}$ ble 4). The overall percent juniper in feces of individual animals (sheep and goats) across treatments and seasons correlated positively with percent time animals spent feeding on juniper $(r=0.59 ; P<0.01, n=152)$. 

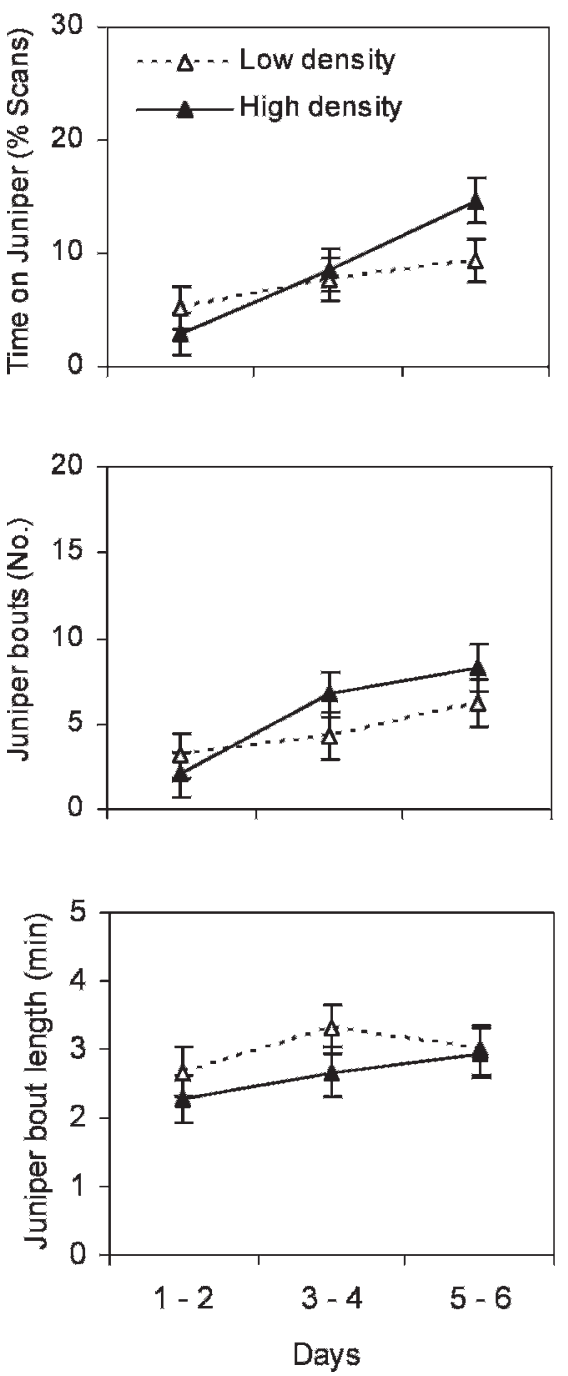
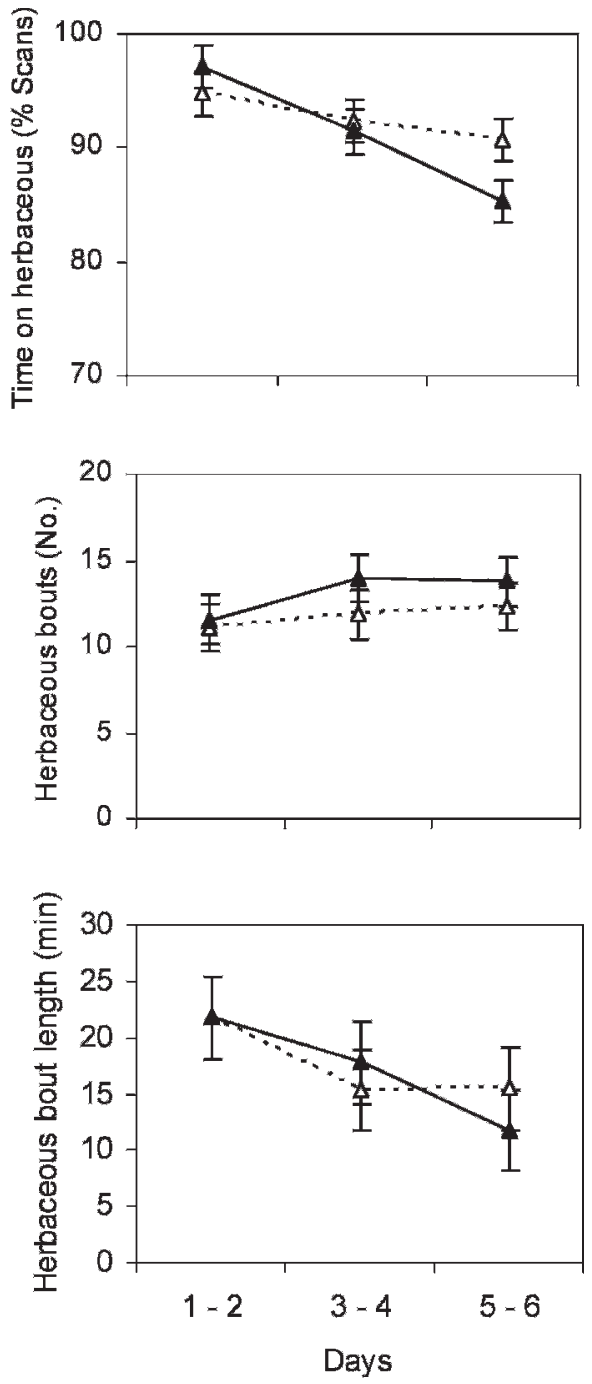

Figure 2. Feeding behavior of sheep in the mixed grazing treatment with goats at high or low stocking density during $6 \mathrm{~d}$ in cells heavily infested with one-seed juniper saplings. Bars denote standard error of means.

\section{Body Weight}

No difference in body weight before and after summer or spring grazing trials was detected for goats and sheep $(P>0.05)$. Across seasons, body weight before and after trials was (means \pm SE) $47.0 \pm 1.5 \mathrm{~kg}$ and $49.4 \pm 1.5 \mathrm{~kg}$ for goats in $\mathrm{MG}, 45.1 \pm 1.5 \mathrm{~kg}$ and $45.2 \pm 1.5 \mathrm{~kg}$ for the goats in GA, and $69.0 \pm 0.9 \mathrm{~kg}$ and $69.2 \pm 0.9 \mathrm{~kg}$ for sheep in MG.

\section{Utilization of Herbaceous Vegetation}

No block $(P=0.75)$ or season $(P=0.28)$ effects were detected in herbaceous vegetation utilization. Herbaceous vegetation utilization was affected by the interaction between stocking density and herbivore species $(P<0.05)$. Mixed-species grazing at high or low stocking density resulted in high levels of herbaceous vegetation utilization $(P>0.05$; Fig. 3$)$, whereas herbaceous vegetation utilization in the GA treatments was higher at low vs. high stocking density $(P<0.05$; Fig. 3$)$. Utilization of herbaceous vegetation ranged between $52 \%$ and $72 \%$ throughout the study.

\section{Juniper Sapling Use}

No block effect was detected for frequency of tall, medium, and short saplings in each defoliation category $(P>0.16)$. Mixedspecies grazing at high stocking density resulted in the highest frequency of heavily defoliated (67-100\% branches defoliated) short saplings (Table 5). Conversely, low stocking density of GA resulted in the highest frequency of lightly defoliated (0$33 \%$ branches defoliated) tall saplings (Table 5). Differences between summer and spring were detected only for the frequency of short saplings receiving heavy defoliation $(P<0.03)$, which was (means $\pm \mathrm{SE}$ ) $74.6 \pm 6.1 \%$ and $51.7 \pm 10 \%$ for summer and spring, respectively. Frequency of saplings in each defoliation category also varied with sapling size; overall, the shorter the sapling, the greater the frequency of saplings with heavy use (Table 6). On average, treatments resulted in about $80 \%$ of saplings with moderate $(34-66 \%)$ to high $(67-100 \%)$ percent of branches defoliated and a remaining $20 \%$ of saplings with low (0-33\%) percent of branches defoliated. 


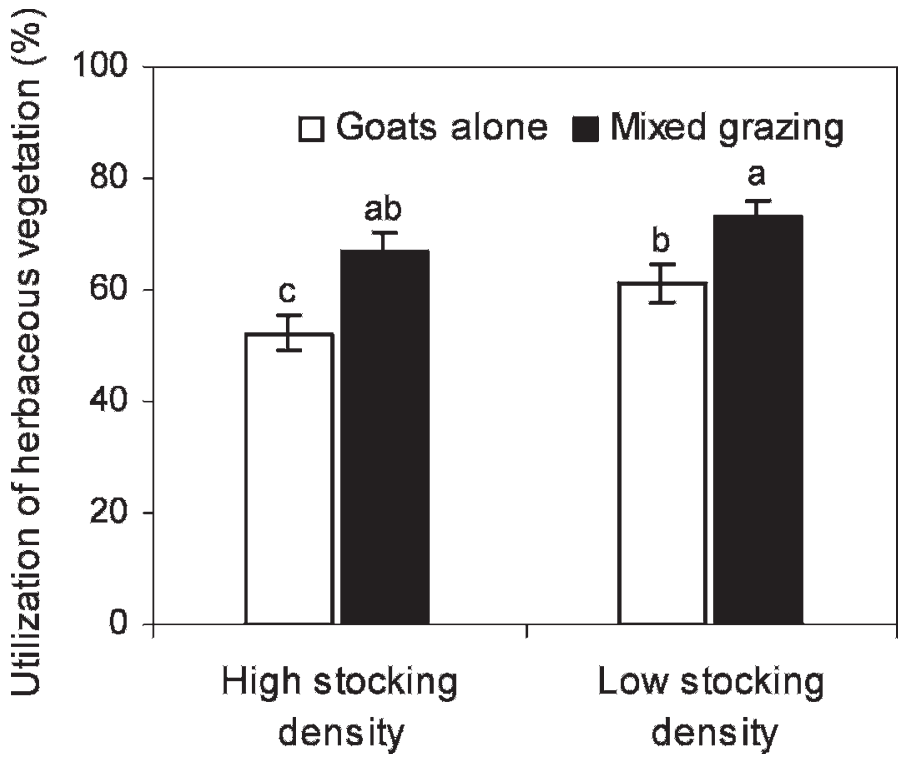

Figure 3. Utilization of herbaceous vegetation biomass in single (goats alone) and mixed-species (goats + sheep) grazing cells subjected to high or low stocking density. Vertical bars represent the standard error of means $(n=16)$. Treatment columns with different letters differ $\left(\mathrm{LSD}_{0.05}\right)$.

No block effect was detected in frequency of tall, medium, and short saplings in each debarking category $(P>0.15)$. Mixed grazing resulted in higher frequency of heavily debarked tall saplings and lower frequency of lightly debarked tall and medium saplings (Table 5). Frequency of short saplings in each debarking category was not affected by grazing treatments (Table 5). Differences between summer and spring grazing were detected for frequency of medium and tall saplings receiving heavy and light debarking. Frequency of heavy debarking was higher in spring than summer for medium $(30.6 \pm 3.4$ vs. $2.6 \pm 1.4 ; P<0.01)$ and tall $(53.3 \pm 6.7$ vs. $14.0 \pm 4.8 ; P<0.01)$ saplings. Conversely, frequency of light debarking was higher in summer than spring for medium $(75.7 \pm 4.5$ vs. $39.7 \pm 5.0 ; P<0.01)$ and tall $(61.7 \pm 7.5$ vs. $24.3 \pm 6.6 ; P<0.01)$ saplings. Frequency of short saplings in each debarking category was not affected by season of grazing $(P>0.40)$. Frequency of saplings in each debarking category also varied with sapling size; overall, the taller the sapling the greater the frequency of saplings with heavy debarking (Table 6).

Utilization of individual branches (\%, length) of tall, medium, and short saplings was not affected by season $(P>0.13)$ or blocks $(P>0.14)$. Branch utilization of tall saplings tended to be higher in MG vs. GA treatments (Table 5). Branch utilization of short saplings, on the other hand, tended to be higher in high vs. low stocking density treatments (Table 5). Although utilization of individual branches did not vary among sapling size categories, the length removed and the residual length were higher for thicker, longer branches of tall and medium saplings (Table 6). Utilization of individual branches depended on initial lengths and diameters. There was an exponential sigmoid relationship between residual and initial length of branches (Fig. 4a). As initial branch length increased and approached maximum value, residual length was predicted to increase up to a maximum of $38.5 \mathrm{~cm}$ (Fig. 4a). Consequently, the length removed was proportionally larger on short vs. long branches and was predicted to increase exponentially up to a maximum of about $17 \mathrm{~cm}$ (Fig. 4b). Longer branches also had thicker stem diameters (Fig. 4c) and cutoff diameters scaled exponentially with the basal diameter of branches (Fig. 4d). A maximum cutoff diameter of $3.5 \mathrm{~mm}$ was predicted for browsed branches (Fig. 4d).

No block effect was detected for change in sapling height, diameter, and volume, frequency of sapling mortality, branch debarking, and branch mortality $(P>0.22)$. All treatments resulted in a significant reduction of sapling height, diameter, and volume and in higher frequency of branch debarking and mortality compared to the control (Table 7). Treatments reduced live canopy sapling height by $0.12 \pm 0.02 \mathrm{~m}$ (mean \pm SE) and live canopy sapling volume by $0.14 \pm 0.05 \mathrm{~m}^{3}$, which represented a $14 \%$ and $15 \%$ reduction of the initial live canopy height and volume of saplings. No difference among the four grazing treatments was detected in sapling mortality (Table 7). Sapling mortality averaged $5 \pm 1.1 \%$ across grazing treatments. Spring grazing resulted in greater reduction of sapling height, diameter, and volume than summer grazing $(P<0.01)$. Although no differences between seasons were detected in sapling mortality $(P=0.43)$, branch mortality tended to be higher $(21.6 \pm 3.0$ vs. $14.6 \pm 2.2 ; P=0.07)$ and the proportion of debarked branches greater $(28.7 \pm 4.0$ vs. $15.6 \pm 1.7 ; P=0.02)$ in spring than summer. Branch debarking was linearly related to branch mortality and changes in height and volume of saplings (Fig. 5).

\section{DISCUSSION}

Goats exhibited higher levels of diet mixing and juniper sapling use in mixed-species high-density grazing situations, thus supporting our first hypothesis. Shaw et al. (2006) reported that the combination of heavy stocking rate (i.e., animals per area per time) and high stocking density (i.e., animals per area) achieved by daily rotation of animals at high densities, resulted in the highest utilization of big sagebrush (A. tridentata) by lambs compared to $3-\mathrm{d}$ rotation schedules or continuous grazing at light stocking rates. Heavy stocking rates are thought to force small ruminants to increase consumption of defended plants, a phenomenon that can be boosted by manipulating stocking density (Shaw et al. 2006) and by mixing ruminant species that exhibit different abilities to cope with plant secondary metabolites (Walker 1994). Heavy stocking rates and high stocking density of small ruminants, as used in this study, appeared to alter diet selection patterns by changing the temporal availability of forages and animal-toforage ratios. In the low stocking density treatments, all plants within grazing cells were available from the first day of trials and thus produced a situation of low animal-to-forage ratio, which encouraged diet selection. Conversely, in the high stocking density treatments, daily forage allowance was always restrictive and animal-to-forage ratios were high, thus restricting diet selection and stimulating juniper utilization.

Goats appeared to increase juniper utilization and intake by adjusting feeding behavior to capitalize on the benefits of diet mixing, especially in the mixed-species high stocking density 
Table 5. Frequency of tall $(>1 \mathrm{~m})$, medium $(0.5-1 \mathrm{~m})$, and short $(<1 \mathrm{~m})$ one-seed juniper saplings that received heavy $(67-100 \%$ branches), moderate (31-66\% branches), or light (0-31\% branches) defoliation or debarking as a result of grazing treatments that resulted from a factorial combination of two herbivores (goats alone or goats mixed with sheep) and two stocking densities (high or low) in summer and spring. Mean ( \pm SE) values within rows followed by different letters differ $\left(\mathrm{LSD}_{0.05}\right)$. The $P$ values are from the mixed-model analysis of variance testing the effect of herbivore species (Herb), stocking density (Dens), and their interaction.

\begin{tabular}{|c|c|c|c|c|c|c|c|c|}
\hline \multirow[b]{2}{*}{ Level of use } & \multirow{2}{*}{$\begin{array}{l}\text { Sapling } \\
\text { size }\end{array}$} & \multicolumn{2}{|c|}{ Goats alone } & \multicolumn{2}{|c|}{ Goats mixed } & \multicolumn{3}{|c|}{$P$ value } \\
\hline & & High & Low & High & Low & Herb & Dens & Herb $\times$ Dens \\
\hline \multicolumn{9}{|l|}{ Saplings } \\
\hline \multicolumn{2}{|l|}{ Defoliated branches (\%) } & -------------------. & sap & gs ---------------- & ------------------ & & & \\
\hline $100-67$ & Tall & $48.9 \pm 2.7$ & $43.4 \pm 2.9$ & $31.9 \pm 10.5$ & $41.9 \pm 7.8$ & 0.228 & 0.755 & 0.305 \\
\hline $66-31$ & & $39.5 \pm 14.5$ & $21.8 \pm 5.9$ & $53.5 \pm 6.4$ & $45.1 \pm 7.3$ & 0.073 & 0.190 & 0.629 \\
\hline $0-30$ & & $11.7 \pm 4.7 \mathrm{~b}$ & $34.8 \pm 5.4 \mathrm{a}$ & $14.5 \pm 4.9 \mathrm{~b}$ & $12.9 \pm 5.1 \mathrm{~b}$ & 0.056 & 0.035 & 0.019 \\
\hline $100-67$ & Medium & $45.6 \pm 8.0$ & $51.5 \pm 7.3$ & $42.5 \pm 10.8$ & $46.0 \pm 8.0$ & 0.510 & 0.480 & 0.855 \\
\hline $66-31$ & & $31.9 \pm 3.2$ & $27.7 \pm 8.6$ & $39.3 \pm 3.8$ & $39.1 \pm 5.4$ & 0.157 & 0.724 & 0.752 \\
\hline $0-30$ & & $22.5 \pm 10.4$ & $20.9 \pm 6.3$ & $18.2 \pm 7.4$ & $15.0 \pm 6.7$ & 0.364 & 0.661 & 0.884 \\
\hline $100-67$ & Short & $56.7 \pm 10.7 b$ & $64.9 \pm 14.1 \mathrm{ab}$ & $87.5 \pm 8.0 \mathrm{a}$ & $43.5 \pm 9.9 b$ & 0.606 & 0.075 & 0.017 \\
\hline $66-31$ & & $28.5 \pm 5.1 \mathrm{a}$ & $16.8 \pm 5.7 \mathrm{ab}$ & $0.0 \pm 0.0 \mathrm{~b}$ & $29.0 \pm 8.2 \mathrm{a}$ & 0.180 & 0.161 & 0.006 \\
\hline $0-30$ & & $14.8 \pm 7.1$ & $18.3 \pm 10.7$ & $12.5 \pm 8.0$ & $27.5 \pm 16.0$ & 0.730 & 0.363 & 0.570 \\
\hline \multicolumn{2}{|l|}{ Debarked branches (\%) } & ---------------- & - & gs --------------- & ------------------ & & & \\
\hline $100-67$ & Tall & $23.6 \pm 15.2$ & $23.8 \pm 10.7$ & $45.2 \pm 11.7$ & $41.9 \pm 14.7$ & 0.018 & 0.833 & 0.806 \\
\hline $66-31$ & & $22.3 \pm 4.8$ & $18.3 \pm 7.4$ & $23.9 \pm 6.2$ & $28.9 \pm 7.4$ & 0.375 & 0.943 & 0.506 \\
\hline $0-30$ & & $54.1 \pm 18.7$ & $57.8 \pm 10.3$ & $30.9 \pm 12.4$ & $29.2 \pm 9.8$ & 0.015 & 0.909 & 0.757 \\
\hline $100-67$ & Medium & $12.9 \pm 8.1$ & $15.1 \pm 7.6$ & $16.8 \pm 8.6$ & $21.6 \pm 10.7$ & 0.196 & 0.375 & 0.738 \\
\hline $66-31$ & & $18.8 \pm 8.6$ & $23.6 \pm 2.5$ & $32.7 \pm 6.2$ & $27.9 \pm 5.6$ & 0.117 & 0.991 & 0.386 \\
\hline $0-30$ & & $68.3 \pm 13.2$ & $61.4 \pm 7.5$ & $50.5 \pm 13.3$ & $50.5 \pm 12.7$ & 0.048 & 0.597 & 0.591 \\
\hline $100-67$ & Short & $4.2 \pm 4.2$ & $5.3 \pm 3.1$ & $3.6 \pm 3.6$ & $2.8 \pm 2.8$ & 0.615 & 0.959 & 0.756 \\
\hline $66-31$ & & $11.3 \pm 7.0$ & $2.5 \pm 2.5$ & $11.3 \pm 7.0$ & $5.6 \pm 5.6$ & 0.800 & 0.246 & 0.800 \\
\hline $0-30$ & & $84.5 \pm 9.0$ & $92.2 \pm 2.6$ & $85.1 \pm 10.1$ & $91.7 \pm 8.3$ & 0.998 & 0.390 & 0.943 \\
\hline \multicolumn{9}{|l|}{ Branches } \\
\hline \multirow[t]{4}{*}{ Overall utilization (\%) } & & 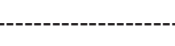 & ----- \% Le & th ------------- & ----------------- & & & \\
\hline & Tall & $44.2 \pm 5.0$ & $42.0 \pm 2.3$ & $47.1 \pm 3.8$ & $47.6 \pm 4.6$ & 0.054 & 0.411 & 0.962 \\
\hline & Medium & $47.3 \pm 2.0$ & $46.4 \pm 1.5$ & $44.1 \pm 1.1$ & $43.4 \pm 6.1$ & 0.430 & 0.660 & 0.880 \\
\hline & Short & $54.1 \pm 1.7$ & $45.8 \pm 3.1$ & $51.5 \pm 4.9$ & $42.6 \pm 4.1$ & 0.433 & 0.080 & 0.928 \\
\hline
\end{tabular}

treatment. Sheep, on the other hand, exhibited more rigid feeding behaviors and were therefore less likely to increase juniper consumption. Goats, which exhibit greater diet versatility than sheep, tended to exhibit increased number and length of juniper feeding bouts, whereas their herbaceous vegetation feeding bouts (which were relatively longer than juniper bouts) remained unchanged or decreased over time. This feeding pattern may have allowed goats to dilute juniper toxins or, alternatively, may have promoted longer interjuniper feeding bouts to allow toxin elimination. Simulations of terpene kinetics show that length of foraging bouts on terpene-rich plants can influence voluntary intake because detoxification capacity of animals may be underexploited if feeding bouts are few and short, or oversaturated if feeding bouts are frequent and long (Foley et al. 1999, Wiggins et al. 2006). Adjustment in the number and length of feeding bouts and interbouts (switching to nutritious plants) allows animals to overcome high concentrations of toxins and to maximize intake. Dziba et al. (2006) showed lambs dosed with 1,8cineole (a toxic terpenoid) stopped feeding sooner than noninfused lambs. These results possibly reflected the relatively fast (minutes) pattern of absorption and elimination of plasma 1,8-cineole, which would explain short-term trends in the duration and frequency of feeding bouts of lambs (Dziba et al. 2006). Flexible diet mixing behaviors are critical to maximizing intake when food options include plants with secondary metabolites (Wiggins et al. 2006). In this study, goats previously exposed and adapted to eat juniper were apparently able to increase utilization of one-seed juniper as days progressed due to adjustments in diet mixing behaviors that were induced by mixed-species grazing and high stocking density.

Low stocking density treatments apparently induced temporal dissociation between the ingestion of herbaceous plants and juniper. Goats in these treatments only increased time spent feeding on juniper toward the end of the 6-d trials when herbaceous plants had been almost completely depleted. Conversely, goats in high-density treatments mixed nutritious herbaceous forages and juniper early on. In other words, intake of juniper and herbaceous plants had short temporal delay (within a given day) for high stocking density and was more temporally disjoined (over several days) for low stocking density. Dissociated patterns of forage intake over days may prevent diet complementarity of nutrients (green grasses and 
Table 6. Frequency of tall $(>1 \mathrm{~m})$, medium $(0.5-1 \mathrm{~m})$, and short $(<1 \mathrm{~m})$ one-seed juniper saplings that received heavy $(67-100 \%$ branches), moderate (31-66\% branches), or light (0-31\% branches) defoliation or debarking by goats and sheep in summer and spring. Mean ( \pm SE) values within rows followed by different letters differ $\left(\mathrm{LSD}_{0.05}\right)$. The $P$ values are from the mixed-model analysis of variance testing the effect of sapling size category as the independent variable. Data are pooled over all grazing treatments.

\begin{tabular}{|c|c|c|c|c|}
\hline \multirow[b]{2}{*}{ Level of use } & \multicolumn{3}{|c|}{ Sapling size } & \multirow[b]{2}{*}{$P$ value } \\
\hline & Tall & Medium & Short & \\
\hline \multicolumn{5}{|l|}{ Saplings } \\
\hline \multicolumn{5}{|l|}{ Defoliated branches (\%) } \\
\hline $0-30$ & $18.5 \pm 3.3$ & $19.1 \pm 3.6$ & $18.3 \pm 5.1$ & 0.988 \\
\hline $31-66$ & $40.0 \pm 5.1 \mathrm{a}$ & $34.5 \pm 2.8 \mathrm{a}$ & $18.6 \pm 3.9 b$ & 0.002 \\
\hline $67-100$ & $41.5 \pm 4.4 \mathrm{~b}$ & $46.4 \pm 4.0 \mathrm{~b}$ & $63.1 \pm 6.4 \mathrm{a}$ & 0.010 \\
\hline Debarked branches (\%) & - & -- \% Saplings & (1) & \\
\hline $0-30$ & $43.0 \pm 6.8 b$ & $57.7 \pm 5.7 \mathrm{~b}$ & $88.4 \pm 3.7 \mathrm{a}$ & $<0.001$ \\
\hline $31-66$ & $23.4 \pm 3.1 \mathrm{a}$ & $25.7 \pm 3.0 \mathrm{a}$ & $7.7 \pm 2.8 b$ & $<0.001$ \\
\hline $67-100$ & $33.6 \pm 6.4 \mathrm{a}$ & $16.6 \pm 4.0 \mathrm{~b}$ & $3.9 \pm 1.6 b$ & $<0.001$ \\
\hline \multicolumn{5}{|l|}{ Branches } \\
\hline Length initial $(\mathrm{cm})$ & $22.3 \pm 1.2 \mathrm{a}$ & $20.1 \pm 0.9 a$ & $16.0 \pm 0.8 b$ & $<0.001$ \\
\hline Length residual $(\mathrm{cm})$ & $12.9 \pm 1.1 \mathrm{a}$ & $11.4 \pm 0.8 \mathrm{a}$ & $8.7 \pm 0.7 b$ & 0.005 \\
\hline Length removed $(\mathrm{cm})$ & $9.4 \pm 0.4 \mathrm{a}$ & $8.8 \pm 0.4 \mathrm{a}$ & $7.4 \pm 0.3 b$ & 0.002 \\
\hline Utilization, length (\%) & $47.7 \pm 1.8$ & $45.8 \pm 1.6$ & $44.6 \pm 1.9$ & 0.554 \\
\hline Basal diameter (mm) & $4.3 \pm 0.3$ & $4.3 \pm 0.4$ & $3.7 \pm 0.3$ & 0.409 \\
\hline Diameter cutoff $(\mathrm{mm})$ & $2.6 \pm 0.1 \mathrm{a}$ & $2.6 \pm 0.1 \mathrm{a}$ & $2.1 \pm 0.1 \mathrm{~b}$ & 0.009 \\
\hline
\end{tabular}
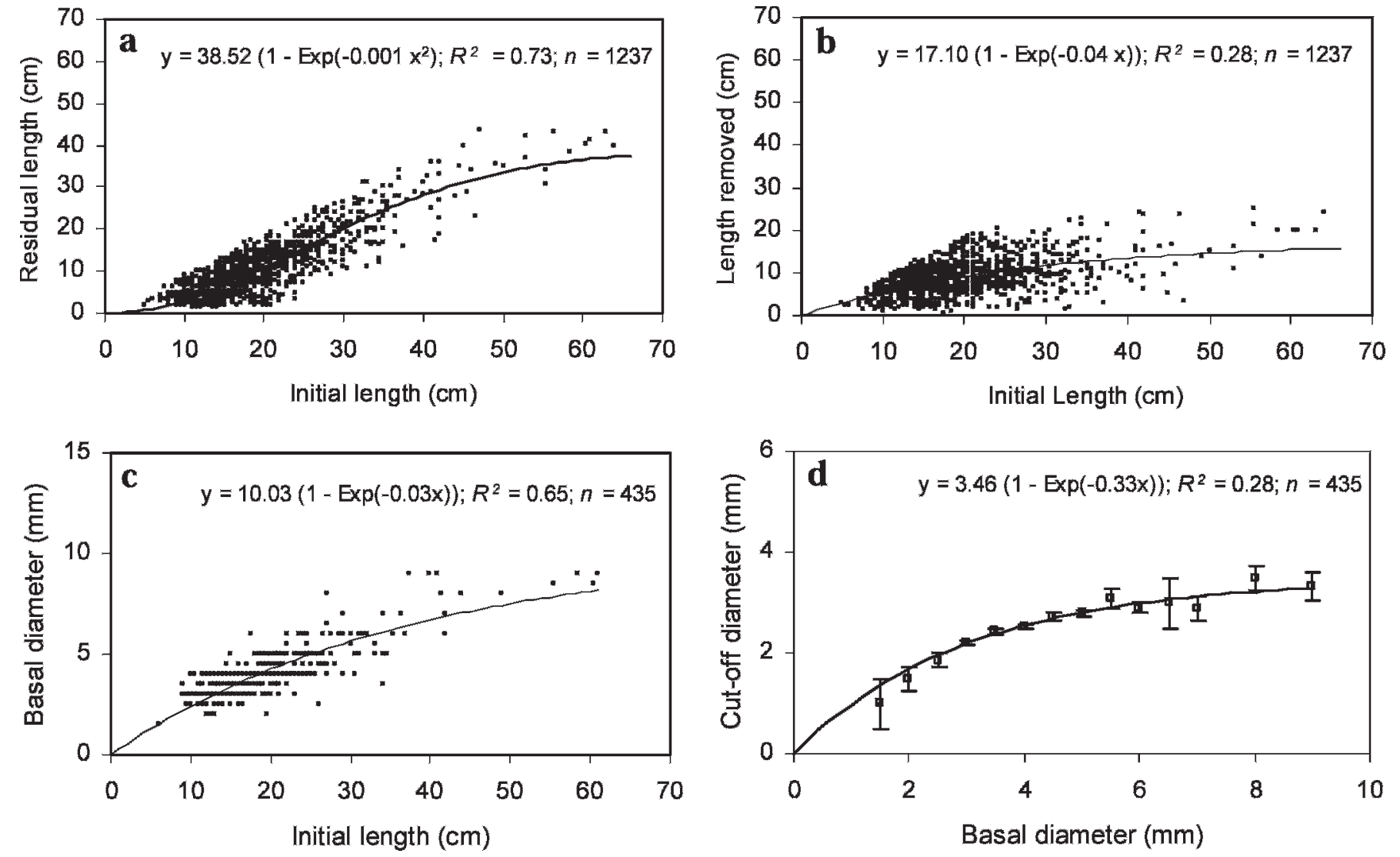

Figure 4. Influence of initial length and diameter on the utilization of one-seed juniper branches. Relationship between $\mathbf{a}$, initial (before grazing) and residual (left after grazing) length of branches; $\mathbf{b}$, initial length of branches and length of branches removed; $\mathbf{c}$, initial length and basal diameter of branches; and $\mathbf{d}$, basal diameter of branches and cutoff diameter. Solid lines represent the relationship between variables depicted by exponential regression models. 
Table 7. Structural change and mortality of one-seed juniper saplings as a result of grazing treatments (Trt) that resulted from a factorial combination of two herbivores (goats only or goats mixed with sheep) and two stocking densities (high or low), or no grazing (control) in summer and spring. The $P$ values are from the analysis of variance testing the effect of grazing treatments. Values are means \pm standard error. Different letters within rows indicate detectable differences at $P<0.05$.

\begin{tabular}{|c|c|c|c|c|c|c|}
\hline \multirow[b]{2}{*}{ Level of use } & \multirow[b]{2}{*}{ Control } & \multicolumn{2}{|c|}{ Goats only } & \multicolumn{2}{|c|}{ Goats mixed } & \multirow{2}{*}{$\frac{P \text { value }}{\text { Trt }}$} \\
\hline & & High & Low & High & Low & \\
\hline \multicolumn{7}{|l|}{ Saplings } \\
\hline Height change (m) & $0.08 \pm 0.01 \mathrm{a}$ & $-0.10 \pm 0.04 b$ & $-0.10 \pm 0.04 b$ & $-0.16 \pm 0.05 b$ & $-0.12 \pm 0.04 b$ & 0.002 \\
\hline Diameter change $(\mathrm{m})$ & $0.07 \pm 0.02 \mathrm{a}$ & $-0.03 \pm 0.04 b$ & $-0.03 \pm 0.05 b$ & $-0.06 \pm 0.03 b$ & $-0.06 \pm 0.03 b$ & 0.005 \\
\hline Volume change $\left(\mathrm{m}^{3}\right)$ & $0.25 \pm 0.06 \mathrm{a}$ & $-0.09 \pm 0.05 b$ & $-0.12 \pm 0.15 b$ & $-0.16 \pm 0.10 b$ & $-0.20 \pm 0.11 b$ & 0.006 \\
\hline Mortality (\%) & $0 \pm 0.0 \mathrm{~b}$ & $4 \pm 2.9 a b$ & $1 \pm 0.8 \mathrm{~b}$ & $6 \pm 2.6 \mathrm{a}$ & $3 \pm 2.0 a b$ & 0.048 \\
\hline \multicolumn{7}{|l|}{ Branches } \\
\hline Debarked (\%) & $0 \pm 0.0 b$ & $19.1 \pm 0.8 \mathrm{a}$ & $15.5 \pm 4.1 \mathrm{a}$ & $24.8 \pm 7.8 \mathrm{a}$ & $27.6 \pm 5.8 \mathrm{a}$ & 0.004 \\
\hline Mortality (\%) & $0 \pm 0.0 \mathrm{~b}$ & $16.6 \pm 1.6 \mathrm{a}$ & $12.6 \pm 3.0 \mathrm{a}$ & $21.7 \pm 6.4 \mathrm{a}$ & $21.5 \pm 3.2 \mathrm{a}$ & 0.002 \\
\hline
\end{tabular}

forbs) and toxins (juniper), thus depressing intake of defended plants such as juniper (Villalba et al. 2002, 2006; Provenza et al. 2007). Juniper contains potentially toxic plant secondary metabolites (PSM), such as condensed tannins, soluble phenolics, and terpenes (Nunez-Hernandez et al. 1989; Utsumi et al. 2006, 2009) and therefore the voluntary intake of this plant over multiple meals may increase when ingestion is associated with nutritious foods or supplements (i.e., protein) offered simultaneously (Campbell et al. 2007) or immediately after the juniper meal (Utsumi et al. 2009). The temporal contiguity between the ingestion of juniper and nutritious alternatives free of PSM may promote dilution of toxins and/or enhance a ruminant's ability to detoxify phenolics and terpenes and thus ameliorate the postingestive effect of juniper. Villalba et al. (2006) demonstrated that lambs fed a high-quality forage $(15 \%$ crude protein) and a food rich in tannins $(10 \%$ condensed tannins) in contiguous sequential meals within a day exhibited higher intake of the tannin-rich food than when both foods were fed with delays of $2 \mathrm{~d}$. Thus, preference for plants with high concentrations of secondary metabolites is likely to increase when meals of nutritious alternatives (without PSM) and defended plants occur in close temporal proximity. We contend that high stocking density may encourage diet mixing by promoting close temporal contiguity among forage options. Experiments conducted with big sagebrush suggest that animals could be trained to learn the benefit of short-term mixing of nutritious and defended plants and increase intake of defended plants through time (Provenza et al. 2007).

Mixed grazing with sheep may have induced interspecific competition for herbaceous understory. Sheep and goats differ physiologically, morphologically, and behaviorally and consequently exhibit different feeding styles that could affect their capacity to cope with plant secondary metabolites (Van Soest 1994). Van Dyne et al. (1980) reviewed 200 studies that collectively showed that sheep and goats can consume about $50 \%$ and $30 \%$ grasses, $30 \%$ and $10 \%$ forbs, and $20 \%$ and $60 \%$ browse, respectively. These data confirm the well-known ability of goats to switch diets between grass and browse, even though woody species usually contain chemical defenses. In this study, sheep spent about $92 \%$ of the time feeding on grasses and forbs and only $8 \%$ on juniper. In contrast, goats in the mixed-species grazing treatment spent twice as much time feeding on juniper when stocking density was low (18\%), and approximately quadrupled time feeding on juniper when stocking density was high $(33 \%)$. Reduction of daily forage allowance as occurred in the high stocking density treatments may have augmented dietary niche separation of sheep and goats (Walker 1994). When cograzing with sheep, goats may try to reduce competition for shared forages by using a different (and exclusive) food niche such as juniper (Animut and Goestch 2008), particularly if preferred forages become limiting. This induced reduction in diet overlap would trigger an increase in juniper utilization by goats, particularly if stocking density is high.

The highest utilization of herbaceous understory occurred in the mixed-species low stocking density treatment, supporting our second hypothesis. Utilization of grasses and forbs was approximately $72 \%$ and $52 \%$ for the MG low-density and GA highdensity treatments, respectively. Juniper sapling utilization levels followed the reverse pattern. These results suggest that relatively high defoliation of saplings could be achieved with mixed-species grazing, but more severe utilization of the herbaceous understory occurred whenever sheep were present regardless of stocking density. The use of a higher number of goats in a single-species grazing prescription, on the other hand, results in a higher goat to sapling ratio and may reduce the impact on herbaceous vegetation while maximizing damage to juniper saplings.

Although a large proportion of saplings received moderate to high levels ( $>33 \%$ branches) of defoliation, there was a remnant of about $20 \%$ of saplings that escaped potentially damaging levels of herbivory. This may have been the result of high plant to plant variation in chemical defense, which is common in one-seed juniper saplings even when growing in relatively close proximity (Utsumi et al. 2006). Interestingly, this defoliation pattern appeared to vary with sapling size/age category and treatments. For instance, the mixed-species high stocking density treatment resulted in higher frequency of shorter saplings with heavy defoliation. Contrary to the general observation of trade-offs in resource allocation between chemical defense and growth of most rangeland woody species (Bryant et al. 1991; Swihart and Bryant 2001), this greater vulnerability to herbivory of shorter juvenile juniper saplings could be attributed to lower chemical defense in younger leaf tissue (i.e., needle leaf stage) as compared to taller saplings with more mature leaf (i.e., scaled leaf stage) tissue (Lyons et al. 

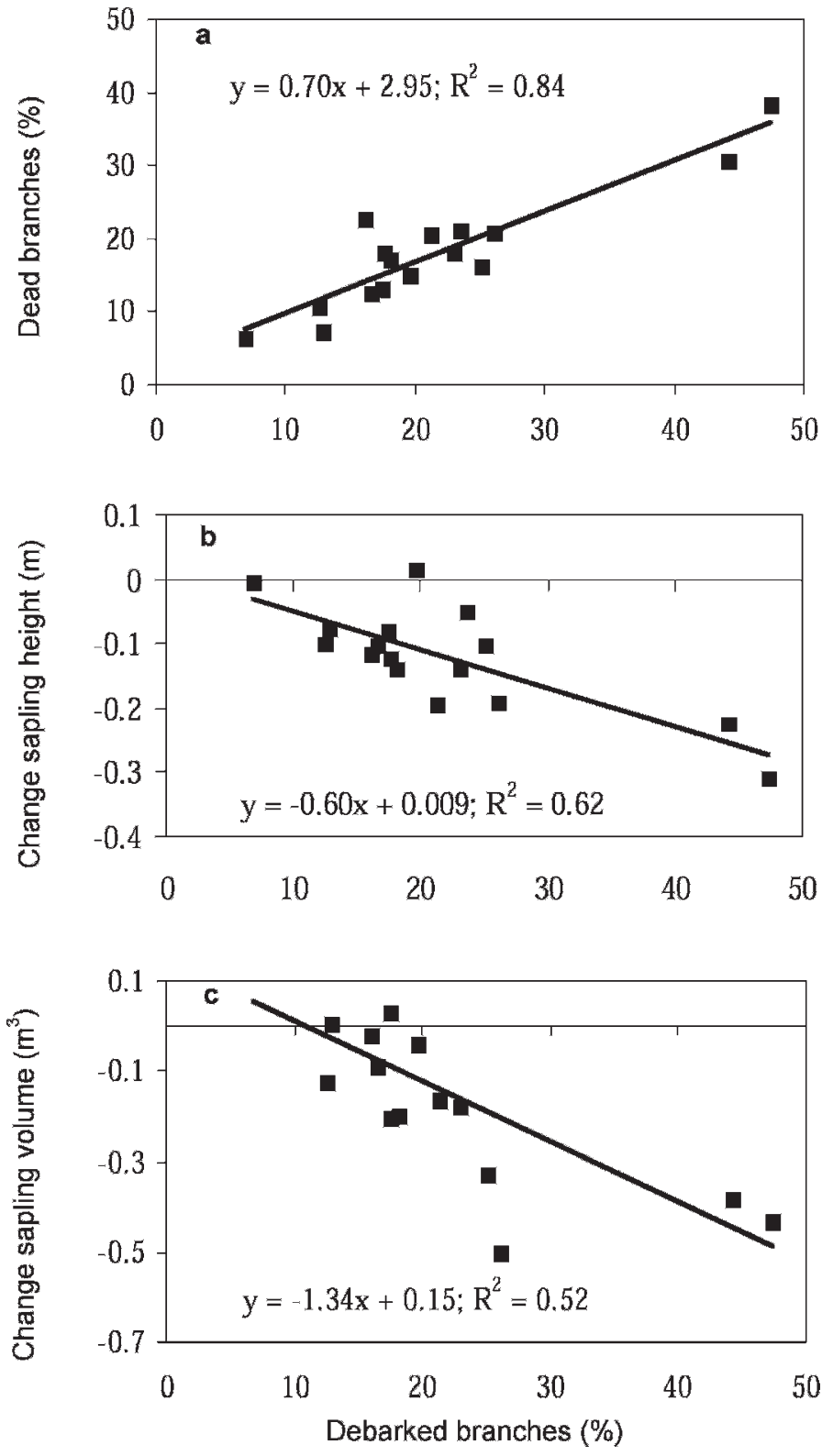

Figure 5. Influence of debarking on branch mortality and crown morphology. Relationship between proportion of branches debarked and $\mathbf{a}$, proportion of dead branches; $\mathbf{b}$, change in sapling height; and $\mathbf{c}$, change in sapling volume. Changes in sapling height and volume are expressed as the difference between dimensions recorded immediately before the grazing treatments were applied and dimensions recorded $2 \mathrm{yr}$ after the study. Solid lines represent the relationship depicted by linear regression models. Plot means for summer and spring treatments $(n=16)$ are shown in each graph.

1998; Utsumi et al. 2006; Campbell and Taylor 2007). Heavier utilization of shorter juvenile saplings was also more evident in the summer, when one-seed juniper leaves exhibit lowest concentration of mono- and sesquiterpenes, soluble phenolics, and condensed tannins (Utsumi et al. 2009). Thus, differences in concentration of plant secondary metabolites, sapling development stage, and season may influence the probability of a plant being browsed and therefore its susceptibility for control with small ruminant herbivory.
The mixed-species high stocking density grazing treatment was also associated with greater frequency of saplings with high percent of debarked branches. Bark girdling and stripping of branches was more frequently observed and branch mortality more often recorded for the spring grazing trials when saplings were resuming growth after the dormant season. Interestingly, sapling size also appeared to be related to level of debarking, because a greater frequency of tall vs. short saplings suffered heavy debarking of branches. Taller, older saplings offered more bark that was easier to access and possibly less defended than mature leaves. Conversely, smaller saplings with younger tissues possibly contained lower levels of chemical defenses (Lyons et al. 1998; Utsumi et al. 2006; Campbell and Taylor 2007) and exhibited fewer effective architectural barriers, which made them more vulnerable to intense defoliation. Thus, a combination of spring (greater utilization of bark on taller saplings) and summer (greater defoliation of smaller saplings) grazing could have synergistic effects on juniper sapling suppression.

In this study, mortality was more likely to occur at the branch rather than the plant level, probably because the animal-to-sapling ratio used was insufficient to stimulate debarking and use of all branches available within a plant. Sapling mortality was $5 \%$ on average and was similar across all grazing treatments, contrary to what we had hypothesized. Branch mortality, on the other hand, ranged from $13 \%$ to $22 \%$ among treatments, and was higher in spring (when debarking was highest) than in summer. Debarking explained almost $80 \%$ of branch mortality and much of the suppression in sapling live canopy height and volume. Removal of bark (phloem) by hand or browsing usually results in high tree/sapling mortality because it blocks translocation of photosynthates, which are necessary for plant growth and survival (Purohit et al. 2001). Girdling the bark from the entire circumference of a branch was necessary to kill a sapling branch at our study site (S. A. Utsumi, unpublished data, 2007). Conversely, branches that received partial bark stripping tended to survive. This observation agrees with prior studies conducted with planted slash pine where $100 \%$ girdling of the circumference of saplings near ground line was necessary to kill saplings (Lewis 1980). Thus, enticing goats to girdle the bark on sapling branches (particularly during spring) may be necessary to suppress juniper sapling growth and increase mortality.

Length and diameter of one-seed juniper branches affected defoliation intensity, thus supporting our fourth hypothesis. Our analyses suggest that utilization declined as branch length increased and stem diameter exceeded $3.5 \mathrm{~mm}$. Thicker stem diameters may increase browsing effort required, therefore protecting older branches from severe defoliation. As branch length and basal diameter increased, so did the postbrowsing residual plant material, a phenomenon that would favor survival of larger saplings, even if most branches were defoliated. As stems became shorter and thinner, a greater proportion of branch length was removed, thus favoring branch depletion and eventually sapling control. Vulnerability of young juniper tissues, therefore, appears to be twofold; on the one hand, they are thought to contain lower levels of chemical defense and, on the other hand, are structurally more vulnerable to higher levels of defoliation. 


\section{MANAGEMENT IMPLICATIONS}

This study suggests that specialized grazing systems could be used to increase voluntary intake of one-seed juniper saplings by goats without compromising the herbaceous understory or the welfare of goats. Targeted grazing prescriptions that involve mixed-species high stocking density grazing in summer and late spring could be used to induce goats to increase diet mixing habits and enhance voluntary intake of juniper. Multiseason grazing strategies will possibly be most successful in suppressing juniper sapling encroachment. Further research is needed to determine the herbivory levels needed to promote a biologically significant reduction in sapling survival rates.

\section{ACKNOWLEDGMENTS}

Special thanks are given to Carolina Fabbi, Shad Cox, Michael Rubio, and Dr Tim Ross, all of whom collaborated with the logistics and conducting of this study. Dr Derek Bailey and Dr Dawn VanLeeuwen provided valuable comments on earlier versions of this manuscript. We are thankful to an anonymous reviewer and the associate editor for suggestions that improved this article.

\section{LITERATURE CITED}

Animut, G., And A. L. Goestch. 2008. Co-grazing of sheep and goats: benefits and constraints. Small Ruminant Research 77:127-145.

ARCHER, S. 1995. Herbivore mediation of grass-woody plant interactions. Tropical Grasslands 29:218-235.

Armentrout, S. M., and R. D. Pieper. 1988. Plant distribution surrounding Rocky Mountain pinyon pine and one-seed juniper in south-central New Mexico. Journal of Range Management 41:139-143.

ARnold, J. F. 1964. Zonation of understory vegetation around a juniper tree. Journal of Range Management 17:41-42.

BonHAm, C. D. 1989. Measurements for terrestrial vegetation. New York, NY, USA: Wiley. 338 p.

Bryant, J. P., P. J. Kuropat, P. B. Reichardt, and T. P. Clausen. 1991. Controls over the allocation of resources by woody plants to chemical antiherbivory defense. In: R. T. Palo and C. T. Robbins [EDS.]. Plant defenses against mammalian herbivory. Boca Raton, FL, USA: CRC Press. p. 83-102.

Campbell, E. S., AND C. A. TayloR. 2007. Monoterpene production in redberry juniper foliage following fire. Rangeland Ecology and Management 60:104-109.

Campbell, E. S., C. A. Taylor, J. W. Walker, C. J. Lupton, D. F. Waldron, and S. Y. Landau. 2007. Effects of supplementation on juniper intake by goats. Rangeland Ecology and Management 60:588-595.

Dziba, L. E., J. O. Hall, and F. D. Provenza. 2006. Feeding behavior of lambs in relation to kinetics of 1,8 -cineole dosed intravenously or into the rumen. Journal of Chemical Ecology 32:391-408.

Foley, W. J., G. R. IAson, and C. McArthuR. 1999. Role of plant secondary metabolites in the nutritional ecology of mammalian herbivores: how far have we come in 25 years? In: H. Jung and G. C. Fahey [EDS.]. Nutritional ecology of herbivores. Proceedings of the Vth International Symposium on the Nutrition of Herbivores; 11-17 April 1999; San Antonio, TX, USA. Savoy, IL, USA: ASAS. p. 130-210.

Freeland, W. J., and D. H. Janzen. 1974. Strategies in herbivory by mammals: the role of plant secondary compounds. American Naturalist 108:269-286.

Jameson, D. A. 1966. Pinyon-juniper litter reduces growth of blue grama. Journal of Range Management 19:214-217.

JAMESON, D. A. 1967. The relationship of tree overstory and herbaceous understory vegetation. Journal of Range Management 20:247-249.

JAMESON, D. A. 1970. Juniper root competition reduces basal area of blue grama. Journal of Range Management 23:217-218.
Launchbaugh, K., and J. W. Walker. 2006. Targeted grazing-a new paradigm for livestock management. In: K. Launchbaugh and J. Walker [EDS.]. Targeted grazing: a natural approach to vegetation management and livestock enhancement. Englewood, CO, USA: American Sheep Industry Association. p. 2-8.

LewIS, C. 1980. Simulated cattle injury to planted slash pine: girdling. Journal of Range Management 33:337-339.

Littell, R. C., P. R. Henry, and C. B. Ammerman. 1998. Statistical analysis of repeated measures data using SAS procedures. Journal of Animal Science 76:1216-1231.

Lyons, R. K., M. K. Owens, and R. Machen. 1998. Juniper biology and management in Texas. Texas Agricultural Extension Service. Uvalde, TX, USA: The Texas A\&M University system. $10 \mathrm{p}$.

Majumdar, S. 2006. The economic value for range forage production [masters thesis]. Las Cruces, NM, USA: College of Agriculture and Home Economics, New Mexico State University. $117 \mathrm{p}$.

National Research Council. 1981. Nutritional requirements of goats: angora, dairy, and meat goats in temperate and tropical countries. Washington, DC, USA: National Academy Press. 100 p.

National Research Councli. 1985. Nutritional requirements of sheep. 6th ed. Washington, DC, USA: National Academy Press. 99 p.

Nunez-Hernandez, G., J. L. Holechek, J. D. Wallace, M. L. Gaylean, A. Tembo, R. Valdez, AND M. CÁrdenAs. 1989. Influence of native shrubs on nutritional status of goats: nitrogen retention. Journal of Range Management 42:228-232.

Pieper, R. D. 1990. Overstory-understory relations in pinyon-juniper woodlands in New Mexico. Journal of Range Management 43:413-415.

Pritz, R. K., K. L. Launchbaugh, and C. A. Taylor. 1997. Effects of breed and dietary experience on juniper consumption by goats. Journal of Range Management 50:600-606.

Provenza, F. D., J. J. Villalba, J. Haskell, J. W. Adam, T. C. Griggs, and R. D. Wiedmeler. 2007. The value to herbivores of plant physical and chemical diversity in time and space. Crop Science 47:382-398.

Purohit, A., R. K. MaikhuRI, K. S. Rao, and S. Nautiyal. 2001. Impact of bark removal on survival of Taxus baccata L. (Himalayan yew) in Nanda Devi Biosphere Reserve, Garhwal Himalaya, India. Current Science 81:586-590.

Riddle, R. R., C. A. Taylor, J. E. Huston, and M. M. Kothmann. 1999. Intake of ashe juniper and live oak by angora goats. Journal of Range Management 52:161-165.

Riddle, R. R., C. A. Taylor, M. M. Kothmann, and J. E. Huston. 1996. Volatile oil contents of ashe and redberry juniper and its relationship to preference by Angora and Spanish goats. Journal of Range Management 49:35-41.

Romme, W. H., C. D. Allen, J. D. Balley, W. L. Baker, B. T. Bestelmeyer, P. M. Brown, K. S. Elsenhart, L. Floyd-Hanna, D. W. Huffman, B. F. Jacobs, R. F. Miller, E. H. Muldavin, T. W. Swetnam, R. J. Tausch, and P. J. Weisberg. 2008. Historical and modern disturbance regimes, stand structure, and landscape dynamics in pinyon-juniper vegetation of the western U.S. Fort Collins, CO, USA: Colorado Forest Restoration Institute. $35 \mathrm{p}$.

SAS. 2004. SAS Documentation ${ }^{\circledR}$ version 9.1.3. Cary, NC, USA: SAS Institute Inc. Schauer, C. S., K. K. Sedivec, T. C. Faller, J. D. Dahl, and S. Kronberg. 2004. Multispecies grazing and single species grazing on leafy spurge infested rangeland. Coordination of sheep and goats research and education programs for the western states. Western Coordinating Committee 39:33-37.

Schott, M. R., AND R. D. Pieper. 1985. Influence of canopy characteristics of oneseed juniper on understory grasses. Journal of Range Management 38:328-331.

Schwartz, C. C., J. G. Nagy, and W. L. Regelin. 1980a. Juniper oil yield, terpenoid concentration, and antimicrobial effects on deer. Journal of Wildlife Management 44:107-113.

Schwartz, C. C., W. L. Regelin, and J. G. Nagy. 1980b. Deer preference for juniper foliage and volatile oil treated foods. Journal of Wildlife Management 44:114-120.

Shaw, R. A., J. J. Villalba, and F. D. Provenza. 2006. Influence of stocking density and rate and temporal patterns of forage allocation on the diet mixing behavior of sheep grazing sagebrush steppe. Applied Animal Behavior Science 100:207-218. 
SWiHARt, R. K., AND J. P. Bryant. 2001. Importance of biogeography and ontogeny of woody plants in winter herbivory by mammals. Journal of Mammology 82:1-21.

UECKERT, D. N. 1997. Biology and ecology of redberry juniper. In: C. A. Taylor, Jr. [ED.]. 1997 Juniper Symposium. San Angelo, TX, USA: Texas A\&M University Research \& Extension Center. p. 5.23-5.34.

us Department of Agriculture natural Resources Conservation Service. 2009. Ecological site description system for rangeland and forestland. Available at: http://esis.sc.egov.usda.gov. Accessed 5 May 2009.

US Department of Agriculture Soll Conservation Service. 1970. Soil survey Torrance area New Mexico. Washington, DC, USA: US Government Printing Office. $149 \mathrm{p}$.

Utsumi, S. A., A. F. Cibils, R. E. Estell, S. A. Soto-Navarro, and D. Van Leeuwen. 2009. Seasonal changes in one seed juniper intake by sheep and goats in relation to dietary protein and plant secondary metabolites. Small Ruminant Research 81:152-162.

Utsumi, S. A., A. F. Cibils, R. E. Estell, and Y. Wang. 2006. Influence of plant material handling protocols on terpenoid profiles of one-seed juniper saplings. Rangeland Ecology and Management 59:668-673.

Van Dyne, G. M., N. R. Brockington, Z. Sxocs, J. Duek, And C. A. Ribic. 1980. Large herbivore sub-systems. In: A. I. Breymeyer and G. M. Van Dyne [EDs.]
Grasslands, systems analysis and man. Cambridge, United Kingdom: Cambridge University Press. p. 269-537.

Van SoESt, P. J. 1994. Nutritional ecology of the ruminant. 2nd ed. Ithaca, NY, USA: Cornell University Press. $476 \mathrm{p}$.

Villalba, J. J., F. D. Provenza, and J. P. Bryant. 2002. Consequences of the interaction between nutrients and plant secondary metabolites on herbivore selectivity: benefits and detriments for plants? Oikos 97:282-292.

Villalba, J. J., F. D. Provenza, and R. Shaw. 2006. Initial conditions and temporal delays influence preference for foods high in tannins and for foraging locations with and without foods high in tannins by sheep. Applied Animal Behavior Science 97:190-205.

WalkeR, J. W. 1994. Multispecies grazing: the ecological advantage. Sheep Research Journal (special issue):52-64.

Walker, J. W., E. S. Campbell, C. J. Lupton, C. A. Taylor, JR., D. F. Waldron, and S. Y. LANDAu. 2007. Effects of breed, sex, and age on the variation and ability of fecal near-infrared reflectance spectra to predict the composition of goat diets. Journal of Animal Science 85:518-526.

Wigins, N. L., C. McArthur, And N. W. Davies. 2006. Diet switching in a generalist mammalian folivore: fundamental to maximizing intake. Oecologia 147: 650-657. 